\title{
Forage yield and quality of a dense thorny and thornless "jurema-preta" stand
}

\author{
Ivonete Alves Bakke ${ }^{(1)}$, Olaf Andreas Bakke ${ }^{(1)}$, Alberício Pereira Andrade ${ }^{(2)}$ and Ignacio Hernan Salcedo ${ }^{(3)}$
}

\begin{abstract}
(1)Universidade Federal de Campina Grande, Dep. de Engenharia Florestal, Caixa Postal 64, CEP 58700-900 Patos, PB, Brazil. E-mail: ivobakke@yahoo.com.br, obakke@cstr.ufcg.edu.br (2)Universidade Federal da Paraíba, Dep. de Solo e Água, Cidade Universitária, CEP 58397-000 Areia, PB, Brazil. E-mail: albericio@uol.com.br (3)Universidade Federal de Pernambuco, Dep. de Energia Nuclear, Av. Prof. Luiz Freire, № 1.000, CEP 50740-540 Recife, PE, Brazil. E-mail: salcedo@ufpe.br
\end{abstract}

\begin{abstract}
The objective of this work was to compare forage production and quality of thorny and thornless "jurema-preta" (Mimosa tenuiflora (Willd.) Poiret) in a dense planted stand, subjected to annual pruning of fine branches, in Patos, PB, Brazil. The experiment consisted of two treatments (thornless and thorny "jurema-preta") in a complete randomized block design, with ten replicates of two linear plots subdivided in time. Forage mass and chemical composition of fine branches and the basal diameter of plants were measured during five years. Pruning decreased $(p<0.05)$ increments in basal diameter and forage production. Annual dry matter yields reached 4,108 and $5,833 \mathrm{~kg} \mathrm{ha}^{-1}$, respectively, for thornless and thorny plants, and forage quality was similar ( $\mathrm{p}>0.05$ ) for both genotypes. This roughage fodder (minimum NDF and ADF averages were $56 \pm 1.1 \%$ and $43 \pm 1.0 \%$, respectively) had low $\mathrm{P}$ and $\mathrm{K}$ concentrations. Its average crude protein content was greater than $9.9 \pm 0.5 \%$, which exceeds the minimum necessary for animal maintenance. Both "jurema-preta" genotypes tolerated pruning of fine branches and contributed with a significant amount of roughage fodder for animal maintenance in the dry season.
\end{abstract}

Index terms: Mimosa tenuiflora, semiarid zones, legume tree.

\section{Produção e qualidade da forragem de jurema-preta com e sem acúleos em plantio adensado}

\begin{abstract}
Resumo - O objetivo deste trabalho foi comparar a produção e qualidade da forragem de jurema-preta (Mimosa tenuiflora (Willd.) Poiret) com e sem acúleos, em plantio adensado, submetida ao corte anual dos ramos finos, em Patos, PB. Utilizou-se delineamento em blocos casualizados, com dois tratamentos (plantas sem acúleos e plantas com acúleos), com dez repetições de duas parcelas lineares subdivididas no tempo. A produção e composição química da forragem de ramos finos e o diâmetro basal das plantas foram medidos durante cinco anos. A poda diminuiu $(\mathrm{p}<0,05)$ o incremento anual do diâmetro basal e a produção de forragem. A produção anual de matéria seca atingiu 4.108 e $5.833 \mathrm{~kg} \mathrm{ha}^{-1}$, respectivamente, em plantas sem e com acúleos, de qualidade forrageira semelhante $(\mathrm{p}>0,05)$ para os dois fenótipos. Este volumoso - valores médios mínimos para FDN e FDA: 56 $\pm 1,1 \%$ e $43 \pm 1,1 \%$, respectivamente - mostrou-se pobre em P e K. Seu teor médio de proteína bruta acima de $9,9 \pm 0,5 \%$ superou o mínimo necessário para a manutenção animal. Os dois genótipos toleraram a poda dos ramos e contribuíram com uma quantidade significativa de volumoso para a manutenção de ruminantes na estação seca.
\end{abstract}

Termos para indexação: Mimosa tenuiflora, trópico semi-árido, leguminosa arbórea.

\section{Introduction}

The native vegetation in semiarid northeastern Brazil is locally known as "caatinga". "Caatinga" is a dry, tropical, deciduous tree-shrub vegetation. About $800,000 \mathrm{~km}^{2}$ of the semiarid region is covered by this vegetation (Lima, 1996), showing different degrees of anthropization due to extraction of wood for fuel and fence posts, slash-andburn agriculture and extensive livestock production (Pereira et al., 2003; Fraga \& Salcedo, 2004). The originally high plant diversity (1,102 identified species) (Drumond et al., 2002; Gamarra-Rojas \& Sampaio, 2002) is affected by slash fires (Sampaio et al., 1993) and their effects persisted six years after burning (Sampaio et al., 1998) or even longer (Pereira et al., 2003). As time following the slash fires increased, "marmeleiro" (Croton sonderianus) and "jurema-preta" (Mimosa tenuiflora (Willd.) Poiret) showed the highest relative densities, but "jurema-preta" presented the highest relative biomass (Sampaio et al., 1998). 
"Jurema-preta" is a widespread pioneer legume tree of many disturbed sites of semiarid Northeastern Brazil (Lima, 1996; Sampaio et al., 1998; Drumond et al., 2002; Pereira et al., 2003). It may grow in dense, pure thickets (Lima, 1996) and its leaves, fine branches and fruits are consumed by ruminants, contributing significantly to animal diet, despite its low digestibility and evidence of digestibility inhibition of grasses (Carvalho \& Salviano, 1982). Collection of this material may yield annually more than $1,500 \mathrm{~kg} \mathrm{ha}^{-1}$ of dry matter (DM) (Vasconcelos \& Araújo Filho, 1985), but handling this material can be troublesome due to the presence of abundant thorns.

Thorns in "jurema-preta" appear in a gradient in which strongly thorn-armed plants grow with less-armed and a few thorn-free plants. The thornless trait must be regulated by a few recessive genes (Carvalho et al., 1999). Clement (1997) explains that growth and productive traits of thornless Bactris sp. and other usually thorny plant species may be decreased, due to homozygosis and endogamous depression. However, thornless plants may be advantageous when considering the easiness of collection and handling and the low risk of animal injury at the moment of browsing. Presence or absence of thorns did not affect hay composition of leaf and fine branches of "sabiá" (Mimosa caesalpiniifolia Benth.) regarding crude protein (17.38\% vs. $18.54 \%$ ) (Pereira et al., 1998), and such information is not avaialable for "jurema-preta". Furthermore, there are no reports about comparative forage yields of thorny and thornless "jurema-preta" stands.

The objective of this work was to compare forage production and quality of thornless and thorny "juremapreta" in a dense planted stand which was subjected to annual pruning of fine branches, in the semiarid region of Patos, PB, in Northeast Brazil.

\section{Material and Methods}

The experimental site was located in the Núcleo de Pesquisa para o Semi-árido (Nupearido), Experimental Station of Universidade Federal de Campina Grande, in Patos, PB ( $7^{\circ} 4^{\prime} 85^{\prime \prime S}$ and $\left.37^{\circ} 16^{\prime} 49^{\prime \prime} \mathrm{W}\right)$ in an Ortic Hypocromic Luvisol with the following physical and chemical characteristics: $88 \%$ of sand, $4 \%$ of silt and $8 \%$ of clay, $\mathrm{pH}$ in water $(1: 2.5)$ of 4.8 , extractable $\mathrm{P}$, $7.7 \mathrm{mg} \mathrm{dm}^{-3}$, and 0.6, 0.4, 1.5, 0.0, 3.6, and $2.4 \mathrm{cmol}_{\mathrm{c}} \mathrm{dm}^{-3}$, respectively, for $\mathrm{K}^{+}, \mathrm{Na}^{+}, \mathrm{H}^{+}+\mathrm{Al}^{3+}, \mathrm{Al}^{3+}, \mathrm{Ca}^{2+}, \mathrm{Mg}^{2+}$ (Embrapa, 1999).
The climate according to the Köppen classification is Aw', with a mean annual rainfall of about $700 \mathrm{~mm}$ concentrated in four to five months, mean daily temperature during the March-July period above $20^{\circ} \mathrm{C}$, that increases to $30^{\circ} \mathrm{C}$ or more during September to December, and annual potential evapotranspiration of approximately 2,000 mm (Bezerra et al., 2004).

Seeds for the field experiment were collected from a thornless "jurema-preta" grove (5x5 m-spacing) located next to the experimental site and from an adjacent thorny "jurema-preta" native thicket. "Jurema-preta" seedlings were grown in $300 \mathrm{~cm}^{3}$ plastic conic containers (tubes) and after 60 days, at the beginning of the rainy season (January 2000), were planted in the field into $4 \mathrm{~cm}$ diameter x $15 \mathrm{~cm}$ deep holes. Seedlings were distributed in a $1 \times 1 \mathrm{~m}$ grid (equivalent to 10,000 plants ha ${ }^{-1}$ ) consisting of seven lines of 14 thornless plants intercalated with seven lines of 14 thorny plants. There was no fertilizer application and weeding was performed twice during the first six months after transplantation. Treatments (thornless "jurema-preta" and thorny "jurema-preta") were randomly assigned to two plots in each of ten blocks. Plots were linear and consisted of six plants; measurements in 2002, 2003, 2004 and 2005 were considered as split-plots.

Measurements of height and basal diameter $(10 \mathrm{~cm}$ above the soil surface) were accomplished in February 2001, April 2002, February 2003, and May 2004. Basal diameter was also measured in May 2005. Height $(\mathrm{cm})$ and basal diameter $(\mathrm{mm})$ were measured, respectively, by means of a graduated rod and a digital caliper.

Forage collection was accomplished in May 2002, May 2003, June 2004, and May 2005. Forage consisted of all leaves and fine branches less than $10 \mathrm{~mm}$ in diameter. All 196 plants were pruned, including those between-plot and external one-line-border plants. Fresh biomass of each plot was weighted, mechanically triturated, sampled and dried in a forced air circulation oven at $65^{\circ} \mathrm{C}$ during 72 hours. Dried samples were weighted, ground to pass through a $1 \mathrm{~mm}$ aperture sieve, and analyzed for neutral (NDF) and acid (ADF) detergent fiber (Van Soest, 1967); for crude protein (CP) after Kjeldahl digestion and distillation of total $\mathrm{N}$, and for ash $\left(550^{\circ} \mathrm{C}\right.$ for 4 hours $)$, according to Silva \& Queiroz (2006). Results were expressed in a $65^{\circ} \mathrm{C}$ DM basis. NDF and ADF were assayed without a heat stable amylase and expressed inclusive of residual ash. 
Subsamples of the forage collected in 2002, 2003 and 2004 were ground to pass a 100-mesh sieve and analyzed for total $\mathrm{P}$ and $\mathrm{K}$ after digestion with sulfuric acid-hydrogen peroxide mixture (Thomas et al., 1967); $\mathrm{P}$ in the digests was analyzed by colorimetry and $\mathrm{K}$ by flame photometer.

Monthly rainfall from January 2001 to December 2005 in Patos was an average from three Climatologic Stations of Embrapa Algodão (Figure 1), and showed large intraand interannual variability, typical of the semiarid region. Precipitation began late in December (179 mm or less) and lasted until June of the following year allowing general plant and tree growth. The July-November period showed no or little (less than $30 \mathrm{~mm}$ per month) precipitation, and is considered the dry season of the year and the period of plant dormancy.

Statistical analyses were run through Statistica, 6.0, subroutine Advanced Linear/Non Linear Models, General Linear Models (StatSoft, 2001). Thorn (T) factor means were compared by ANOVA F test, using the Residue (a) mean square with nine degrees of freedom (DF). The F test for Year (Y) and YxT and YxBlock interactions used the Residue (b) mean square with 27 (basal diameter and forage variable) or 18 (forage $\mathrm{P}$ and $\mathrm{K}$ concentrations) DF, out of 79 or 59 total DF, respectively (Pimentel-Gomes \& Garcia, 2002). Quadratic regression equations were estimated to fit height and diameter data with time.

\section{Results and Discussion}

Mean heights of both "jurema-preta" genotypes showed a quadratic behavior $(\mathrm{p}<0.01)$, since after 3.5 years of growth they returned to the initial value of February, 2001 - 13 months after planting (Figure 2). This trend was attributed to pruning and top desiccation of cut branches. The thorny genotype plants were consistently taller during the experiment, but differences were not statistically significant $(\mathrm{p}>0.05)$.

Both genotypes showed a quadratic increase in basal diameter during the experimental period, but increases were greater for thorny than for thornless plants $(\mathrm{p}<0.01)$ (Figure 2). The quadratic equation used to fit the experimental data should be considered cautiously, since an unplanned browsing by goats during four months

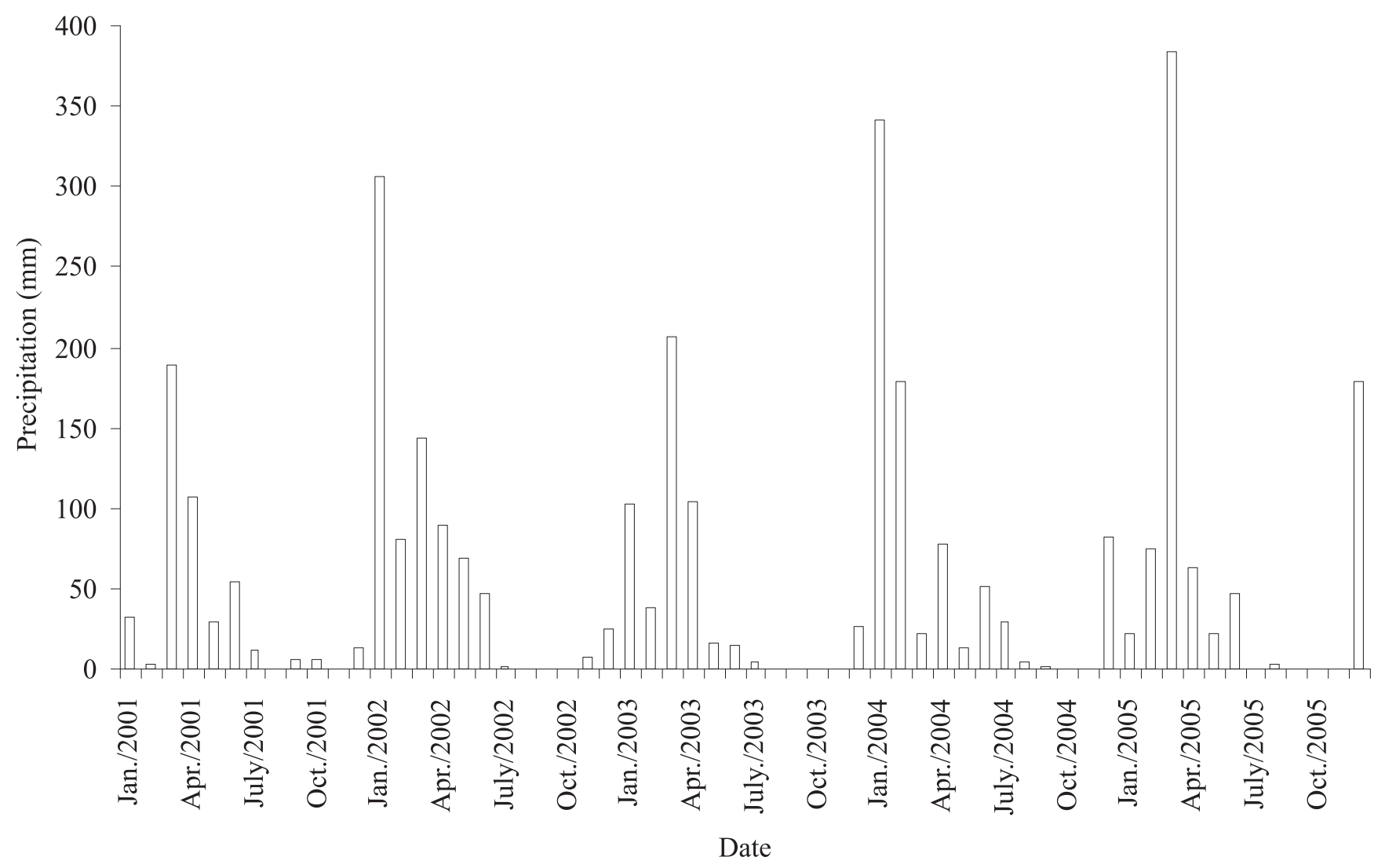

Figure 1. Mean monthly precipitation (mm), in Patos, PB, from January 2001 to December 2005. 
occurred in 2004. This continuous browsing affected the basal diameter growth rate during 2004 and resulted, at 54 months, in a basal diameter that fell beneath the curve. At the end of a four-month period, plants showed no sprouts at all, no broken branches and no nibbled bark, indicating that the animals consumed all the "jurema-preta" and complemented their diet with other forage. Although unplanned, this event helped to demonstrate the adaptation of both "jurema-preta" genotypes to direct browsing, since growth rates in basal diameter during the last year of the experiment were similar to those determined in 2003.

Fresh biomass and dry matter forage yields were affected by thorn and year factors $(\mathrm{p}<0.01)$ but interaction was not significant $(\mathrm{p}>0.05)$ (Table 1$)$. Thorny plants produced $42 \%$ (2002-2003) to 49\% (2002-2005) more forage than thornless ones. Highly thorn-armed individuals may have benefited from a higher heterozygose level, growing faster and producing more than the more homozygous thornless plants. Thornless individuals can be further affected by the consequent endogamous depression (Clement, 1997). This author mentions that thorny Bactris sp. plants produce $7 \%$ more heart-of-palm than thornless
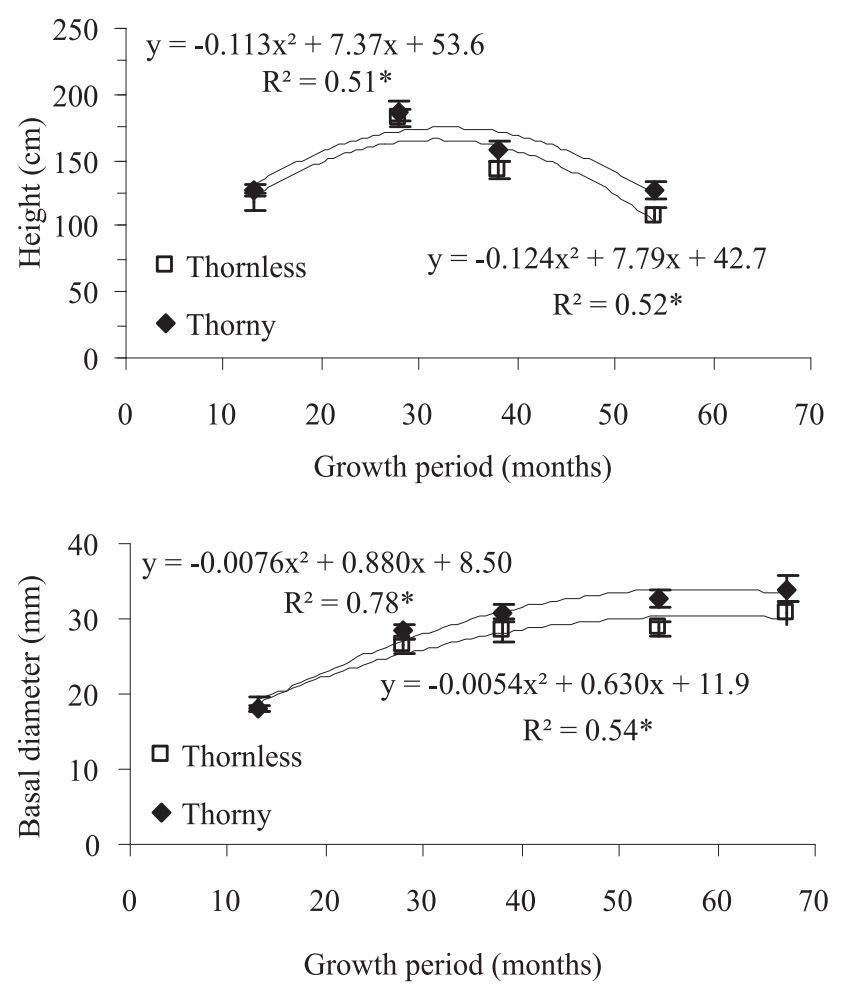

Figure 2. Mean height and basal diameter of thornless and thorny "jurema-preta" (Mimosa tenuiflora) plants of 13 to 54 (height) or 67 months (basal diameter). ones. However, this fact does not prevent producers from growing thornless Bactris sp., probably because easier collection and handling compensate lower production levels, which may also apply to "jurema-preta". The reasons for the lower forage yield of the thornless "jurema-preta" and the possibility to genetically improve its forage production should be further investigated.

Although the unplanned browsing in 2004 prevented formal analysis of the effect of the year factor on forage production (and composition) through regression, it is still possible to discuss these data. Considering only the 2002-2003 data from Table 1, the estimated mean annual forage yields were 4,108 and $5,833 \mathrm{~kg} \mathrm{ha}^{-1}$ of dry matter, for the thornless and thorny plants respectively $\left(10,000\right.$ plant ha $\left.^{-1}\right)$. In 2004 forage yield decreased due to unplanned browsing mentioned, since the growth period was limited to only three months (May-July) and with limited rainfall (Figure 1). If it is assumed that at least a similar amount of forage was consumed by direct browsing during January-April, which had a much better water supply, then forage yield in 2004 would be higher than that of 2005 . Without the actual forage production in 2004, it is not possible to assert if yield in 2005 is indicating stabilization or downward trend in forage production.

Generally, the available tree forage in "caatinga" forest comprises leaves and twigs attached to the tree bellow 1.6 to $1.8 \mathrm{~m}$ plus senescent leaves and fruits that fall on the soil, especially during the dry season. In average, dry matter reaches $400 \mathrm{~kg} \mathrm{ha}^{-1}$ per year (Araújo Filho \& Carvalho, 1996) and stands for a significant forage source. Albuquerque \& Bandeira (1995) hand-plucked forage from caatinga shrubs and trees under five management regimes. The minimum shrub and tree forage stock was $49.7 \mathrm{~kg} \mathrm{ha}^{-1}$, with no manipulation, and the maximum was $235 \mathrm{~kg} \mathrm{ha}^{-1}$ with slashing, of which $214 \mathrm{~kg} \mathrm{ha}^{-1}$ were from "jurema-preta" sprouts. However, these authors considered slashing a relatively expensive practice that may not compensate the total joint tree-shrub-herb increase of forage production (a 167\% increase, from 1,007 to 2,686 $\mathrm{kg} \mathrm{ha}^{-1}$ ). A higher "jurema-preta" forage production $\left(1,500 \mathrm{~kg} \mathrm{ha}^{-1}\right)$ was reported by Vasconcelos \& Araújo Filho (1985). Except for the 2004 data, forage yields in the present study were greater than previously reported, suggesting that the potential of "jurema-preta" forage production may have been underestimated. However, comparisons of forage stocks or productivity among studies should be considered cautiously, because there can be differences in plant density, age of trees and thickness of collected sprouts affecting the results. 
Only one plant in the external border of the experimental area died during the study, although the stand was under a pruning regimen since 2002. This demonstrates the adaptation of both genotypes to the removal of fine branches, suggesting that it may be less stressful for tree-forage production than the clear cut practice reported by Vasconcelos \& Araújo Filho (1985).

Mean DM, NDF, ADF, CP and ash contents (Table 2) were not affected ( $>0.05)$ by the thorn factor, while were positively affected $(\mathrm{p}<0.01)$ by the year factor, except for CP, that peaked in 2004, and DM that showed very small changes. Although no regression model estimation was considered useful, "jurema-preta" forage from both genotypes became more fibrous annually $(\mathrm{p}<0.01)$ (approximately $6.9 \%$ in the whole period), probably as a plant response to annual pruning. The large increase in 2005 is likely a result of direct browsing in the previous year. It is probable that inner cell reserve carbohydrates were mobilized for plant recovery, similarly to what happens to Croton sonderianus (Carvalho et al., 1998), increasing the proportion of fibrous structural carbohydrates (NDF and ADF) present in the outer cell layers.

Mean CP content oscillated between 9.9 and $12.2 \%$, except for 2004, when the young sprouts collected three months after the unplanned browsing showed up to $17.6 \%$ of CP (Table 2). The average $\mathrm{CP}$ concentrations were in the same range as found by Zanine et al. (2005) in "jurema-preta" in Bahia. However, both NDF and ADF concentrations were $10 \%$ higher in this study, in relation to results obtained by Zanine et al. (2005). It is difficult to interpret the significance of this difference, since the degree of natural fluctuation of these parameters among "jurema" stands from different regions is unknown.
Differences in climate, soil, type of forage collection, vegetative stage and genetic variability could certainly cause $10 \%$ fluctuations or more.

No differences $(p>0.05)$ were observed in forage $\mathrm{P}$ and $\mathrm{K}$ concentrations between thorny and thornless plants (Table 3). P content peaked $(\mathrm{p}<0.01)$ in 2004 , from an average $0.62 \mathrm{mg} \mathrm{g}^{-1}$ of dry matter in 2002 and 2003 to $0.70 \mathrm{mg} \mathrm{g}^{-1}$ of dry matter in 2004 , lower if compared to the $1.7-2.5 \mathrm{mg} \mathrm{g}^{-1}$ of dry matter reported for "jurema-preta" and other legume species by Valadares Filho et al. (2001). Probably, low forage $\mathrm{P}$ contents were a consequence of low soil available $\mathrm{P}$, which was in the deficiency range (Embrapa, 1999). As far as forage quality is concerned, mineral mixtures can easily amend $\mathrm{P}$ deficiency in animal diet. Variations in forage $\mathrm{K}$ contents among years were non significant ( $p>0.05)$. Similar concentrations of $\mathrm{K}$ in plant were obtained in a pot experiment with "jurema-preta", also in two soils well supplied in K, while Gliricidia sepium had almost twice as much K (Valadares Filho et al., 2001; Dantas, 2005). More data is needed to confirm if "juremapreta" is a low demanding species for $\mathrm{K}$, as well as a $\mathrm{K}$-poor forage source.

Based on the estimated mean annual forage yields mentioned $\left(4,108\right.$ and 5,833 $\left.\mathrm{kg} \mathrm{ha}^{-1}\right)$ and the mean $\mathrm{P}$ and $\mathrm{K}$ contents in the forage tissue (Table 3 ) (0.65 $\mathrm{g} \mathrm{P} \mathrm{kg}^{-1} \mathrm{DM}$ and $\left.6.82 \mathrm{~g} \mathrm{~K} \mathrm{~kg}^{-1} \mathrm{DM}\right)$, annual exports of soil $\mathrm{P}$ would oscillate between 2.7 and $3.8 \mathrm{~kg} \mathrm{ha}^{-1}$, and of soil $\mathrm{K}$ between 27.9 and $39.6 \mathrm{~kg} \mathrm{ha}^{-1}$. In average, these values represent 21 and $7.2 \%$ of available $\mathrm{P}$ and $\mathrm{K}$ stocks present in the $0-20 \mathrm{~cm}$ soil layer. Although soil nutrient supply is not restricted to this layer, the large proportion of available $\mathrm{P}$ extracted in one year suggests future $P$ limitations in forage production of "jurema-preta" dense stands, if grown in this and similar P deficient soils.

Table 1. Forage yield of thornless and thorny "jurema-preta" (Mimosa tenuiflora), obtained from the annual sprout pruning, in four consecutive years.

\begin{tabular}{|c|c|c|c|c|c|}
\hline \multirow[t]{2}{*}{ Treatments } & \multicolumn{4}{|c|}{ Year factor } & \multirow[t]{2}{*}{ Mean $^{(1)}$} \\
\hline & 2002 & 2003 & $2004^{(2)}$ & 2005 & \\
\hline \multicolumn{6}{|c|}{ Fresh biomass $\left(\mathrm{kg} \mathrm{ha}^{-1}\right)$} \\
\hline Thornless & 6,218 & 7,767 & 2,017 & 3,417 & $4,850 \pm 4.33 b$ \\
\hline Thorny & 8,967 & 10,650 & 3,467 & 5,833 & $7,233 \pm 4.33 \mathrm{a}$ \\
\hline Mean & 7,583 & 9,200 & 2,733 & 4,617 & \\
\hline \multicolumn{6}{|c|}{ Dry matter $\left(\mathrm{kg} \mathrm{ha}^{-1}\right)\left(65^{\circ} \mathrm{C}\right)$} \\
\hline Thornless & 3,600 & 4,617 & 1,217 & 2,017 & $2,867 \pm 2.50 \mathrm{~b}$ \\
\hline Thorny & 5,200 & 6,467 & 2,067 & 3,333 & $4,267 \pm 2.50 \mathrm{a}$ \\
\hline Mean & 4,400 & 5,533 & 1,650 & 2,667 & \\
\hline
\end{tabular}

${ }^{(1)}$ Means in the columns, for each variable, followed by the same letter do not differ at $5 \%$ of probability by F test. (2) Unplanned four-month browsing period during this year. 
Table 2. Dry matter, neutral detergent fiber, acid detergent fiber, crude protein and ash mean contents $\left(\%, 65^{\circ} \mathrm{C}\right.$ basis $)$ of thornless and thorny "jurema-preta" (Mimosa tenuiflora) sprouts in four consecutive years.

\begin{tabular}{|c|c|c|c|c|c|}
\hline \multirow[t]{2}{*}{ Treatments } & \multicolumn{4}{|c|}{ Year factor } & \multirow[t]{2}{*}{ Mean $^{(1)}$} \\
\hline & 2002 & 2003 & $2004^{(2)}$ & 2005 & \\
\hline \multicolumn{6}{|c|}{ Dry matter } \\
\hline Thornless & 57.9 & 59.4 & 60.9 & 59.6 & $59.5 \pm 0.27 \mathrm{a}$ \\
\hline Thorny & 58.0 & 60.8 & 59.8 & 57.9 & $59.1 \pm 0.27 \mathrm{a}$ \\
\hline Mean & 58.0 & 60.1 & 60.3 & 58.7 & \\
\hline \multicolumn{6}{|c|}{ Neutral detergent fiber } \\
\hline Thornless & 59.2 & 58.4 & 61.1 & 65.5 & $61.1 \pm 0.53 \mathrm{a}$ \\
\hline Thorny & 56.1 & 58.6 & 62.5 & 63.6 & $60.2 \pm 0.53 \mathrm{a}$ \\
\hline Mean & 57.6 & 58.5 & 61.8 & 64.5 & \\
\hline \multicolumn{6}{|c|}{ Acid detergent fiber } \\
\hline Thornless & 43.6 & 44.1 & 44.9 & 48.4 & $45.3 \pm 0.51 \mathrm{a}$ \\
\hline Thorny & 43.0 & 44.2 & 46.6 & 47.7 & $45.4 \pm 0.51 \mathrm{a}$ \\
\hline Mean & 43.3 & 44.2 & 45.6 & 48,1 & \\
\hline \multicolumn{6}{|c|}{ Crude protein } \\
\hline Thornless & 9.9 & 12.2 & 17.6 & 10.7 & $12.6 \pm 0.26 \mathrm{a}$ \\
\hline Thorny & 10.1 & 11.7 & 16.9 & 11,3 & $12.5 \pm 0.26 \mathrm{a}$ \\
\hline Mean & 10.0 & 11.9 & 17.2 & 11,0 & \\
\hline \multicolumn{6}{|c|}{ Ash } \\
\hline Thornless & 2.7 & 2.6 & 3.2 & 3.3 & $3.0 \pm 0.05 \mathrm{a}$ \\
\hline Thorny & 2.7 & 2.7 & 3.2 & 3.3 & $3.0 \pm 0.05 \mathrm{a}$ \\
\hline Mean & 2.7 & 2.6 & 3.2 & 3.3 & \\
\hline
\end{tabular}

${ }^{(1)}$ Means in marginal columns, for each variable, followed by the same letter do not differ at $5 \%$ of probability by the F test. (2) Unplanned fourmonth browsing period this year.

Table 3. Concentrations of phosphorus and potassium $\left(\mathrm{mg} \mathrm{g}^{-1}\right.$ of dry matter, $\left.65^{\circ} \mathrm{C}\right)$ in plant tissue of thornless and thorny "jurema-preta" (Mimosa tenuiflora) annual sprouts.

\begin{tabular}{|c|c|c|c|c|}
\hline \multirow[t]{2}{*}{ Treatments } & \multicolumn{3}{|c|}{ Year factor } & \multirow[t]{2}{*}{ Mean $^{(1)}$} \\
\hline & 2002 & 2003 & 2004 & \\
\hline \multicolumn{5}{|c|}{ Phosphorus } \\
\hline Thornless & 0.614 & 0.634 & 0.711 & $0.653 \pm 0.008 \mathrm{a}$ \\
\hline Thorny & 0.627 & 0.624 & 0.698 & $0.649 \pm 0.008 \mathrm{a}$ \\
\hline Mean & 0.621 & 0.629 & 0.704 & \\
\hline \multicolumn{5}{|c|}{ Potassium } \\
\hline Thornless & 6.77 & 6.80 & 6.69 & $6.75 \pm 0.15 \mathrm{a}$ \\
\hline Thorny & 7.33 & 6.70 & 6.65 & $6.89 \pm 0.15 \mathrm{a}$ \\
\hline Mean & 7.05 & 6.75 & 6.67 & \\
\hline
\end{tabular}

${ }^{(1)}$ Means in marginal columns, for each variable, followed by the same letter do not differ at $5 \%$ of probability by the $\mathrm{F}$ test.

\section{Conclusions}

1. Pruning fine branches of "jurema-preta" late in the dry season yields up to $5,833 \mathrm{~kg} \mathrm{ha}^{-1}$ per year of forage that is useful as roughage fodder to amend the diet of small ruminants during the period of food scarcity.

2. Thorny "jurema-preta" produces more forage than the thornless ones, but forage quality of both genotypes is similar and the easiness of forage collection and handling of the thornless trait can compensate for its lower production level.
3. Forage crude protein content of both genotypes is greater than the minimum necessary for animal maintenance, but the high forage fiber content can reflect negatively in food intake and digestibility.

4. Concentrations of $\mathrm{P}$ and $\mathrm{K}$ contents are lower than reported for other legume forages, which agree with low soil available $\mathrm{P}$ but not with high soil available $\mathrm{K}$ concentrations.

\section{Acknowledgements}

To Capes, for the scholarship granted to the first author; to $\mathrm{CNPq}$, for financial support. 


\section{References}

ALBUQUERQUE, S.G. de; BANDEIRA, G.R.L. Effect of thinning and slashing on forage phytomass from a caatinga of Petrolina, Pernambuco, Brazil. Pesquisa Agropecuária Brasileira, v.30, p.885-981, 1995.

ARAÚJO FILHO, J.A. de; CARVALHO, F.C. de. Desenvolvimento sustentado da caatinga. In: ALVAREZ VENEGAS, V.H.; FONTES, L.E.F.; FONTES, M.P.F. (Ed.). O solo nos grandes domínios morfoclimáticos do Brasil e o desenvolvimento sustentado. Viçosa: SBCS, 1996. p.125-133.

BEZERRA, J.E.S.; FERREIRA, L.A.; LINS, J.R.P.; PONTES, J.R.; MELO, S.T. Caracterização física do Estado da Paraíba. In: BEZERRA, J.E.S. (Ed.). Atualização do diagnóstico florestal do Estado da Paraíba. João Pessoa: Sudema, 2004. p.17-82.

CARVALHO, F.C. de; ARAÚJO FILHO, J.A. de; RÊGO, M.C.; TELES, F.F.F. Flutuações dos níveis dos carboidratos de reserva disponíveis nas raízes e no caule do marmeleiro (Croton sonderianus Muell. Arg.). Revista Brasileira de Zootecnia, v.27, p.672-675, 1998.

CARVALHO, J.H.; MAIA, C.M.N.A.; AMORIM. G.C. Seleção de sabiá (Mimosa caesalpiniifolia) sem acúleos no meio norte. In: QUEIROZ, M.A.; GOEDERT, C.O.; RAMOS, S.R.R. (Ed.). Recursos genéticos e melhoramento de plantas para o Nordeste brasileiro. Petrolina: Embrapa-Cpatsa; Embrapa-Cenargen, 1999. Available at: <http://www.cpatsa.embrapa.br $>$. Accessed on: 13 Nov. 2004.

CARVALHO FILHO, O.M. de; SALVIANO, L.M.C. Evidências da ação inibidora da jurema preta na fermentação in vitro de gramíneas forrageiras. Petrolina: Embrapa-CPATSA, 1982. 15p. (Boletim de pesquisa, 11).

CLEMENT, C.R. Pupunha, recursos genéticos para a produção de palmito. Horticultura Brasileira, v.15, p.186-191, 1997.

DANTAS, J.S. Absorção de N, P e K de três espécies florestais em relação ao estresse hídrico e adubação orgânica em dois solos do semi-árido da Paraíba. 2005. 36p. Dissertação (Mestrado) - Universidade Federal da Paraíba, Areia.

DRUMOND, A.M.; KIILL, L.H.P.; NASCIMENTO, C.E. de S. Inventário e sociabilidade de espécies arbóreas e arbustivas da caatinga na região de Petrolina, PE. Brasil Florestal, v.74, p.37-43, 2002.

EMBRAPA. Centro Nacional de Pesquisa de Solos. (Rio de Janeiro, RJ). Sistema brasileiro de classificação de solos. Brasília: Embrapa-SPI; Rio de Janeiro: Embrapa-CNPS, 1999. 412p.

FRAGA, V. da S.; SALCEDO, I.H. Declines of organic nutrient pools in tropical semi-arid soils under subsistence farming. Soil Science Society of America Journal, v.68, p.215-224, 2004.

GAMARRA-ROJAS, C.F.L.; SAMPAIO, E.V. de S.B. Espécies de caatinga no banco de dados do CNIP. In: SAMPAIO, E.V. de S.B.;
GIULETTI, A.M.; VIRGÍNIO, J.; GAMARRA-ROJAS, C.F.L. (Ed.). Vegetação e flora da caatinga. Recife: APNE-CNIP, 2002. p.50-91.

LIMA, J.L.S. Plantas forrageiras das caatingas: usos e potencialidades. Petrolina: Embrapa-Cpasa/PNE/RB-KEW, 1996. 52p.

PEREIRA, I.M.; ANDRADE, L.A.; SAMPAIO, E.V. de S.B.; BARBOSA, M.R.V. Use-history effects on structure and flora of caatinga. Biotropica, v.35, p.154-165, 2003.

PEREIRA, V.L.A.; AZEVEDO, A.R.; LIRA, M.A.; VASCONCELOS, F.A.; ALVES, A.A. Composição químicobromatológica do "mulch" e do sabiá (Mimosa caesalpiniifolia, Benth.) inerme e com acúleos. Revista Brasileira de Zootecnia, v.35, p.666-668, 1998.

PIMENTEL-GOMES, F.; GARCIA, C.H. Estatística aplicada a experimentos agronômicos e florestais: exposição com exemplos e orientações para uso de aplicativos. Piracicaba: Fealq, 2002. 309p.

SAMPAIO, E.V. de S.B.; ARAÚJO, E. de L.; SALCEDO, I.H.; TIESSEN, H. Regeneração da vegetação de caatinga após corte e queima, em Serra Talhada, PE. Pesquisa Agropecuária Brasileira, v.33, p.621-632, 1998.

SAMPAIO, E.V. de S.B.; SALCEDO, I.H.; KAUFFMAN, J.B. Effect of different fire severities on coppicing of caatinga vegetation in Serra Talhada, PE. Brazil. Biotropica, v.25, p.452-460, 1993.

SILVA, D.J.; QUEIROZ, A.C. Análise de alimentos: métodos químicos e biológicos. 3.ed. Viçosa: UFV, 2006. 235p.

STATSOFT INCORPORATION (Tulsa, United States of America). Statistica for Windows: version 6.0. Tulsa, 2001. Available at: $<$ http://www.statsoft.com>. Accessed on: Nov. 2005.

THOMAS, R.L.; SHEARD, R.W.; MOYER, J.R. Comparison of conventional and automated procedures for $\mathrm{N}, \mathrm{P}$ and $\mathrm{K}$ analysis of plant material using a single digestion. Agronomy Journal, v.59, p.240-243, 1967.

VALADARES FILHO, S. de C.; ROCHA JÚNIOR, V.R.; CAPELLE, E.R. (Ed.). Tabelas brasileiras de composição de alimentos para bovinos. Viçosa: UFV, 2001. 297p.

VAN SOEST, P.J. Development of a comprehensive system of feed analysis and its application to forage. Journal of Animal Science, v.26, p.119-128, 1967.

VASCONCELOS, S.H.L.; ARAÚJO FILHO, J.A. Influência da frequiência e intensidade de poda sobre a produtividade da jurema preta (Mimosa sp.). Caatinga, v.5, p.27-34, 1985.

ZANINE, A. de M.; SANTOS, E.M.; FERREIRA, D. de J.; ALMEIDA, J.C. de C.; MACEDO JÚNIOR, G. de L.; OLIVEIRA, J.S. de. Composição bromatológica de leguminosas do semi-árido brasileiro. Livestock Research for Rural Development, v.17, 2005. Available at: <http://www.cipav.org.co/lrrd/lrrd17/8/ zani17087.htm>. Accessed on: 15 Nov. 2005.

$\overline{\text { Received on April 10, } 2006 \text { and accepted on December 13, } 2006}$ 